\title{
On Two Expressions for the New Moon in Latin*
}

\author{
Maria N. Kazanskaya \\ Institute for Linguistic Studies of the Russian Academy of Sciences; \\ 9, Tuchkov per., St. Petersburg, 199004, Russian Federation; subura@mail.ru \\ St. Petersburg State University, \\ 7-9, Universitetskaya nab., St. Petersburg, 199034, Russian Federation; m.kazanskaya@spbu.ru
}

For citation: Maria N. Kazanskaya. On Two Expressions for the New Moon in Latin. Philologia Classica 2019, 14(1), 68-83. https://doi.org/10.21638/11701/spbu20.2019.105

The article examines two expressions for the new moon in Latin, luna silens and luna sicca (or sitiens). Despite the unusual imagery behind the choice of these epithets, the expressions appear in unremarkable, technical contexts (mostly, in works on agriculture by Cato, Columella, Pliny the Elder) and denote this particular phase of the lunar cycle without any indication that the metaphors were perceived by speakers. The paper aims at explaining this paradox. It is shown that neither of these expressions was based on superstitions or popular lore. They reflected, in fact, an attempt to present the phase of the lunar cycle when the moon is invisible in contrast to other visible phases, which are easier to identify. Thus, luna silens was created by opposition to luna crescens "the waxing moon", as denoting the moment before active, visible growth will begin. Luna sicca, on the other hand, was created by opposition to luna plena, "the full moon", where the moon would be imagined as a vessel, gradually filled to its fullness by white light. Finally, luna sitiens was an expression, synonymic to luna sicca, created by analogy with luna silens. While these expressions were used as terms without any artistic effect, Augustan poets seem to have recognized their poetic potential and, on some occasions, put it to use (in particular, Verg. Aen. 2, 255 and Prop. 2, 17, 15).

Keywords: new moon, luna silens, luna sicca (sitiens), Cato, Pliny the Elder, Columella, agricultural lore, Vergil, Propertius.

Latin has several expressions for the new moon, i.e. the day that opens the new lunar phase when the Moon is not visible due to it having the same ecliptic longitude as the Sun: ${ }^{1}$ paradoxically, luna nova was not one of them, as the term seems to have been used for the "new moon" in a broader sense, designating the first days of a lunar month. ${ }^{2}$

* An earlier version of this article was presented at the 47th International Philological Research Conference, organized by St. Petersburg State University (March 21-22, 2018). I would like to thank the audience for the discussion of my paper, and in particular, D. V. Keyer for his generous and insightful comments and suggestions.

1 Throughout this article the term "new moon" will be used in this narrow, terminological sense of the moon in conjunction with the sun, and not in the more popular usage that designates the first days of the lunar cycle as the "new moon".

2 Thus, Tavenner 1918, 80; cf. novae lunae in Hor. Carm. 3, 19, 9 (with Nisbet, Rudd 2004, 234 ad

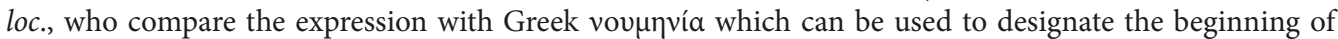
the month. While this parallel is certainly pertinent, there is a slight difference that distinguishes voup pvía in Greek: the term was originally used for the first day of the lunar month considered a holy day, linked to religious celebrations and practices (cf. Mikalson 1972). Thus, there is a transfer of meaning from the astronomical designation of the new moon to the day of the month (cf. Thuc. 2, 28, 1 where the historian stresses

(C) St. Petersburg State University, 2019 
Two expressions, interlunium or luna intermenstrua, were clearly of astronomic origins, referring to the notion of transition from one lunar cycle to another. The idea behind two remaining expressions, luna silens, literally "the silent moon", and luna sicca or luna sitiens, "the dry/thirsty moon", is much less obvious and requires a separate examination. If taken literally, neither the verb sileo, silere nor the adjective siccus are an intuitive choice to qualify the moon, and the resulting expressions, if viewed through the lens of classical Latin, would appear strikingly metaphoric. However, what renders them all the more enigmatic is the fact that both luna silens and luna sicca (sitiens) are attested principally in technical, unpoetic texts, both being more popular with Roman agricultural writers than the more straightforward luna intermenstrua or interlunium. ${ }^{3}$ Moreover, the contexts suggest that for average Latin speakers luna silens and luna sicca (sitiens) were the neutral designation of the particular day of the lunar cycle, while the metaphoric nature of the two epithets seems to have gone largely unnoticed. ${ }^{4}$ This article proposes to explain the origins of the two expressions and to analyze some poetic contexts in which they are used for artistic effect.

Before examining the two designations of the new moon, it is worth making an overview of the denominations of lunar phases; these expressions are fairly well attested, especially, as in agricultural lore different phases were considered appropriate for different agricultural tasks. ${ }^{5}$ The name for the waxing moon in Roman writers is luna crescens (sometimes allowing for periphrastic expressions such as cum luna incrementum capit). ${ }^{6}$ The full moon was called plena luna (more seldom, by a univerbalised term, pleniluni$u m) .{ }^{7}$ The first and last quarter-moon was called dimidia luna or luna dimidiata, ${ }^{8}$ and the waning moon could be designated as luna decrescens, luna senescens, luna minuens or by some kind of periphrasis. ${ }^{9}$ Even a cursory glance at these terms is sufficient to discover a tendency to designate opposite moon phases by antonymic expressions. This is especially evident in the case of luna decrescens / senescens / minuens as opposed to luna crescens, where the coexistence of three terms based on two distinct metaphors shows beyond doubt that luna crescens was the original term, while luna decrescens / senescens / minuens were created either by simple negation or, by antonym, in opposition to two

that he is talking about the vovunvía in the astronomical sense); however, due to the religious dimension, voup days.

${ }^{3}$ For examples of luna intermenstrua and interlunium in agricultural contexts, see Cato, Agr. 37, 4; Plin. HN. 17, 215; 18, 158; 18, 322; 18, 158; etc.

4 This is particularly evident when the expression appears in combinations like luna silenti post meridiem (Cato, Agr. 40, 1; cf. below).

${ }_{6}^{5}$ For the fullest overview of the evidence, see the excellent article by Tavenner (1918).

${ }^{6}$ Columella, Rust.2, 10, 12; for the discussion of this expression, see n. 12.

7 For luna plena, see, e.g., Plin. HN. 14, 134; 17, 215; 18, 322; Colum. De arb. 15; for plenilunium, Columella, Rust.11, 2, 85; Plin. HN. 16, 194; etc. In poetry, the phase of the full moon could also be indicated by applying the epithet plenus to features of the moon: cf., plenos extinxit Cynthia vultus "the moon extinguished her full face" (Petron. Sat. 122, line 130); bis quinos plena cum fronte resumeret orbes / Cynthia, "when the moon regained for the tenth time the orb with the fullness of her brow" (Stat. Theb. 1, 576-577).

8 E. g., Cato, Agr. 37, 4; Plin. HN. 18, 322; Vitr. 9, 2, 3; etc.

${ }^{9}$ For luna decrescens, cf. Columella, Rust.11, 2, 11; 11, 2, 52; Cato, Agr. 31, 2; Plin. HN. 17, 146; 18, 321; etc. For luna senescens, cf. Varro, Rust. 37, 1 and 3; Gell. NA 20, 8, 4 (with the possibility of periphrasis cum senescit luna, cf. Varro, Rust. 1, 64, 1). A less specific kind of expressions for the waning moon were based on the comparative minor, minus: thus, cum luna minuitur (Pallad. 10, 12); and Horace's minorem ad lunam (Sat. 2, 8, 31-32), as Kuijper 1966 has shown, must also refer to the waning moon. 
meanings, literal and metaphorical, of crescere, "grow in size, grow physically" and "grow to adulthood, age". As we shall show, a similar process seems to have been at work in the case of luna silens and luna sitiens (sicca).

\section{Luna silens}

In the preserved texts, the expression luna silens appears almost exclusively in the ablative, the variation of the ending showing that the epithet could be interpreted either as an adjective (in which case the expression becomes an ablative in its temporal function, silenti lunā), or as a participle forming an ablative absolute construction, luna silente. ${ }^{10}$ The verb silere in this expression seems to have never been replaced by a synonym ${ }^{11}$, so that we are dealing with a fixed term. The majority of contexts where luna silenti appears concern advice on sowing, planting or manuring, together with indications of the best season and weather (especially, as regards the winds) for these farming procedures, e.g.:

Alteram quartam partem (scil. stercoris) in pratum reservato idque, cum maxime opus erit, ubi favonius flabit, evehito luna silenti (Cato, Agr. 29).

"Keep the other quarter (of manure) for the field and, when it is most needed, bring it out on the day of the new moon, when west wind blows."

Per ver haec fieri oportet: $\langle\ldots\rangle$ in locis crassis et umectis ulmos, ficos, poma, oleas seri oportet: ficos, oleas, mala, pira, vites inseri oportet luna silenti post meridiem sine vento austro (ibid. 40, 1).

"In spring the following should be done: in places that are rich and moist, elms, figs, apple-trees, olive-trees should be planted; figs, olive-trees, apple-trees, pear-trees, vines should be planted on the day of the new moon, in the afternoon, when there is no south wind."

Prata primo vere stercerato luna silenti: quae inrigiva non erunt, ubi favonius flare coeperit (ibid. 50).

"Fields should be manured in the beginning of spring on the day of the new moon: for they will not be well-watered, once the west wind starts to blow."

Silente luna fabam vellito ante lucem, deinde cum in area exaruerit, confestim, prius quam luna incrementum capiat, excussam refrigeratamque in granarium conferto. (Columella, Rust. 2, 10, 12).

"Gather the beans during the new moon before sunrise; then, after they have dried on the threshing-floor, at once, before the moon gains $<$ noticeable $>$ growth, ${ }^{12}$ stock them in the granary, having beaten them out and cooled them."

${ }^{10}$ It is very probable that the expression silenti luna was the original form, while the ablative absolute was a reinterpretation (this will be discussed in a separate article).

11 A. Ernout in his edition of Pliny reconstructed an expression for the new moon in which silenti would be replaced by tacenti (Ernout 1962, 27-28): Ungues resecari nundinis Romanis <luna > tacenti atque a digito indice multorum persuasione religiosum est, "Cutting nails on the Roman nundinae (market-days) during (the new moon?), and commencing from the forefinger, is considered a bad sign in the opinion of many people" (Plin. HN. 28, 28). The transmitted text is certainly obscure, and it is difficult to understand tacenti as it stands. However, there is no external evidence that tacere could be substituted for silere in the designation of the new moon; moreover, the application of the superstition would be uncharacteristically limited, if the recommendation to avoid cutting nails were restricted to days when the nundinae coincide with the new moon.

12 The expression prius quam luna incrementum capiat is sometimes understood as indicating of the beginning of the waxing moon phase, which necessarily makes the scholars interpret the expression silente 
$<\ldots>$ hoc (scil. vicia, passioli, pabulum) silente luna seri iubent (Plin. HN. 18, 314).

"They advise that these (i.e. vetch-peas, calavance, fodder plants) should be sown in the new moon".

Pliny formulates the general principle of observance of this phase of lunar cycle with regard to agricultural tasks in the following manner:

Inter omnes vero convenit utilissime in coitu eius sterni, quem diem alii interlunii, alii silentis lunae appellant (Plin. HN. 16, 190).

"However, of all days, timber is to be felled with most advantage when the sun and moon come together, on the day that is called by some the midmoon day, and others call the day of the silent moon."

These contexts show that for Latin speakers the expression lunā silenti (silente) was a neutral indication of the lunar phase that could even be combined with an indication of the time of day, amounting in paradoxical expressions of the type luna silenti post meridiem (Cato, Agr. 40, 1) ${ }^{13}$. However, the choice of the verb silere is not self-evident, as the transition from the idea of being silent to the notion of not giving light makes for a fairly bold metaphor. In fact, lemmas in dictionaries have a difficulty of finding an appropriate category for the expression: $O L D$ is a case in point, as it makes a separate entry for lunā silenti. ${ }^{14}$ There have been diverse attempts to explain the use of silere in lunā silenti. Works on Roman religion unsurprisingly associate the epithet silens with the allegorical representation of the moon as a deity (moreover, associated with Hecate); ${ }^{15}$ however, the technical nature of the texts and absence of explicit religious connotations or any stylistic features that usually accompany allegoresis is a serious drawback to accepting this explanation. Another approach linked the use of silere to its association with other forces of nature, in particular, with the winds: ${ }^{16}$ the parallel, however, does not seem appropriate,

luna as referring to the waning moon, not only to the new moon: thus, "Here it is apparent that the dark of the moon is thought of as the remnant of the waning moon; and that if the moon should begin to increase before the harvest was garnered, the beans would not dry successfully" (Tavenner 1918, 70, quoted with approval by Cram 1936, 258). This goes contrary to the specific use of the expression silenti luna to denote the day between two lunar cycles when the moon is invisible. It seems much better to understand the expression prius quam luna incrementum capiat as referring to a stage of the waxing phase, when the moon's incrementum clearly seen. Unfortunately, I was unable to ascertain how long it takes for beans to dry; intuitively, during a dry summer several days under the sun might suffice, so that the moon would not even have to reach the dimidia luna stage. Alternatively, D. V. Keyer has suggested to me that the words prius quam luna incrementum capiat might be a gloss on silente luna that was accidentally incorporated into the main text, rendering Columella's instructions practically unfeasible (he considers that the beans would have to dry for a longer period of time), and hence Palladius' correction to luna minuente in his rendering of the same advice (Pall. 7, 3, 2). However, as the expression incrementum capere is rare, I would prefer to keep Columella's text as it is and to understand incrementum as noticeable growth: Columella's lack of precision in this case could be explained by varying delays for the process depending on how dry or moist the season is.

13 This paradoxical usage is often remarked on by scholars: Shackleton Bailey 1947, 90; Heyworth 2007, 187 n. 51.

${ }^{14}$ See OLD 1968, 1761, s.v. silens, -ntis.

15 Thus, Lunais 1979, 335; Green 2007, 134. Tavenner 1918, 81-82 was certainly right when he insisted that agricultural lore (i.e. the system of practical observations and beliefs according to which a Roman farmer scheduled his activities) should be distinguished from religious beliefs and practices.

16 That the semantic development was thus reconstructed is evident from the lemma in Georges 1886, Bd. II, 2390-2391, s.v. sileo, partic. silens (b). For this usage of silere, cf. verumtamen praestat eligere sationi 
as the choice of silere is not unexpected when speaking of a natural phenomenon which, in its stronger manifestations is associated with sound. Finally, Ernout and Meillet in their discussion of the use and etymology of the verb silere, indicate (implicitly rather than explicitly) that luna silenti might have originated with the use of silere in the vegetal sphere. ${ }^{17}$ Indeed, an overview of agricultural contexts in which the verb silere appears shows a number of contexts connected to growth (especially of vegetation), to indicate the moment that immediately precedes active, visible growth - the moment when the plant has all the potential for bringing forth new branches and stems, is ready for it but no signs of growth are as yet apparent: ${ }^{18}$

quae (scil. sarmenta et calamenta) sicco tamen solo legenda sunt, ne lutosa humus inculcata maiorem fossori laborem praebeat, qui protinus adhuc silentibus vineis inducendus est (Columella, Rust.4, 27, 1).

"These (scil. prigs and deadwood) should be gathered while the ground is dry, so that the trampling of muddy earth does not render the task more difficult for the digger, who should be sent for at once, while the vines are still dormant".

$<\ldots>$ eoque debemus intellegere nullam partem anni excipi, si sit sarmenti silentis facultas (ibid. $4,29,1)$.

"And for that we must understand that no part of the year should be an exception, should there be any capacity for growth of prigs (i. e. in plants that are as yet dormant)."

In these passages the verb is applied to perennial plants so that the idea behind the expression silentibus vineis is contrasted with antequam germinent $(4,27,1)$, as well as that behind sarmenti silentis with sine germine $(4,29,1)$. It should be noted specifically that the verb silere in the sense of expectation of active growth tends to be used in the present participle, focusing on the dormant state; it can also be applied to eggs that have not yet hatched:

$<\ldots>$ nam post unum et vicesimum diem silentia oua carent animalibus (ibid. 8, 5, 15). ${ }^{19}$

"For eggs that are not hatched after twenty-one days have no living creature in them."

silentis vel certe placidi spiritus diem, "however, for sowing it is best to choose a day of no wind, or a gentle one" (Columella, Rust. 3, 19, 3); [...] diem quoque tepidum silentemque a ventis eligat "let him choose a warm and windless day" (Columella, Rust. 4, 29, 5). It was also popular in poetry: ibi omnes silent venti... "there all winds are silent..." (Plin. Epist. 2, 17, 7); unde hiemes ventique silent "thence tempests and winds are silent" (Stat. Ach. 1, 54); silet umidus aer "moist air is silent" (Ov. Met. 7. 187); aequora tuta silent, "the safe sea is silent”" (Verg. Aen. 1, 164); cur adhuc undae silent? "why are waves still silent?" (Sen. Phaedr. 954).

17 See Ernout-Meillet 1967, 625 who mention the expression luna silenti between the uses of silere for forces of nature and its use for plants and vegetative growth; cf. also Kazanskaya (forthcoming).

18 The lemma in OLD 1968, 1761, s.v. sileo, groups very different usages under the last meaning " 5 To be inactive, be quiet. $\mathbf{b}$ (of processes, actions, etc. not to function, be quiescent. $\mathbf{c}$ (of plants, etc.) to be dormant; (of eggs) to show no sign of activity, i.e. not to hatch": the problem is that the lemma does not distinguish between the use of the verb for artistic effect and terminological use where no such effect is apparent. Cf. Lunais 1979, 337 who remarks: "Dans ces deux cas (scil. Cic. Mil. 10 and Tac. Hist. 3, 47 - M. K.) ; l'image se comprend d'elle-même ; le français peut la garder sans la déformer. Il en va tout autrement de la lune 'silencieuse'».

19 D. V. Keyer suggests that the usage of silere in silentia ova may in fact have been the primary metaphor, and that thence the verb was transferred to the vegetative sphere. Unfortunately, the expressions are not sufficiently well attested (silentia ova occurs only once) to decide which of them was primary and which was secondary. 
The usage of silere to designate the period immediately preceding growth, when all the potential for growing is in place but the process has not yet begun, corresponds exactly to the meaning that we were looking for in luna silenti: the choice of silere for the periphrasis was at once accurate and technical, as it characterized the astronomical phenomenon (the period when the moon is not visible) by means of the antonym to crescere that described its positive counterpart (the period when the moon grows). The metaphor behind silere thus equated the lunar cycle to the cycle of vegetative growth, which, given the persistency of beliefs in the connection between the growth of the moon and the growth of plants, hair, young animals, ${ }^{20}$ made the expression luna silenti all the more natural and acceptable. It should be stressed however that this connection was secondary.

\section{Luna sicca (sitiens)}

The expressions lunā siccā "during the dry moon" and lunà sitiente "during the thirsty moon" seem to have been less current than lunā silenti. As in the case of luna silenti, the epithet is clearly metaphorical, but the dictionaries offer no clue as to which meaning of siccus and sitiens the expression is grounded on. ${ }^{21}$ In Roman sources, Pliny the Elder is the only one to use it, and it is also from him that we learn of the existence of an analogous expression, lunā sitiente:

$<\ldots>$ fimum inicere terrae plurimum refert favonio flante ac luna sitiente. id plerique prave intellegunt a favonii ortu faciendum ac Februario mense tantum, cum id pleraque sata <et $>$ aliis postulent mensibus. quocumque tempore facere libeat, curandum, ut ab occasu aequinoctiali flante vento fiat lunaque decrescente ac sicca. mirum in modum augetur ubertas effectusque eius observatione tali (Plin. HN. 17, 57).

"It pays best to manure the ground when the west wind is blowing and the moon is thirsty. The majority wrongly take it that this should be done when the west wind sets in and only in the month of February, whereas most crops need manuring in other months as well. ${ }^{22}$ Whatever the season when it is done, one must take care to do it when the wind blows from due west (i.e. west as the point of sunset on the equinoxes - M.K.) and when the moon is waning or dry. Observing $<$ this rule $>$ increases fertility and the effectiveness of the procedure."

Given that the expression is not otherwise attested, and that Pliny is here closely following Cato (Agr. 29, 1, passage cited above), it does not come as a surprise that there have

20 Among plants, animals and other entities whose development was linked by the Romans to the growing phase of the moon, sources mention lentils (Pallad. 3, 4), reeds (Plin. HN. 17, 108); trees in general (Columella, Rust. 5, 11, 2; De arb. 29, 1; Cato, Agr. 40, 1), eggs (Plin. HN. 18, 322, cf. Columella, Rust. 8, 5, 9 - the logic behind Columella's advice is aptly explained by Tavenner 1918, 77-78), hair and wool (Varro, Rust. 1, 37), oysters and other mollusks (Cic. Div. 2, 33-34), etc. The general principle guiding farmers' choice of the lunar phase was laid down by Palladius: omnia quae seruntur crescente luna et diebus tepidis sunt serenda "all cultures that are sown should be sown during the waxing moon and on warm days" (Pallad. 1, 6, 12). For a thorough discussion of this belief, see Tavenner 1918, passim; cf. Riess 1893, col. 39-40 and Roscher 1890, 61-67.

${ }^{21}$ OLD ignores the expressions luna sicca and luna sitiens (see OLD 1968, 1754-1755, s.v. siccus; 1774, s.v. sitiens).

22 Manuscripts of Pliny give aliis, and the conjunction et was added by H. Rackham in his Loeb edition. This is a fortunate addition from the point of view of style and content: <et $>$ aliis mensibus nicely balances Februario mense tantum; and a number of crops are indeed regularly given additional, albeit lighter, manuring during the months of their growth. 
been attempts at correcting the text. Ferdinandus Pintianus (Latin name of the Spanish humanist Hernán Núñez de Toledo y Guzmán), based on a comparison with Cato’s discussion of manuring the fields, surmised that the expression lunā sitiente must be equivalent to luna silenti, and concluded from it that in Pliny sitiente should be modified to silenti. ${ }^{23}$ Although the equivalence is certainly correct, editors of Natural History are right to reject his correction, ${ }^{24}$ as it gives preference to the lectio facilior over the interesting rarer variant. The second example of lunā sitiente occurs in the same book of Naturalis historia, and in this case as well the transmitted text provoked certain doubts:

Inseri autem praecipit pira ac mala per ver et post solstitium diebus $L<$ et $>$ post vindemiam, oleas autem et ficos per ver tantum, luna sitiente, [hoc est sicca] praeterea post meridiem ac sine vento austro $(17,112)$.

"[Cato] advises that the pear and apple trees be grafted during the spring, and fifty days after midsummer and after the vintage, whereas the olive and fig trees only in the spring, when the moon is thirsty [i.e. dry], moreover, in the afternoon and not when a south wind is blowing."

Once again, Pliny follows Cato (in this case, referring to him by name), conflating two distinct passages from De agricultura..$^{25}$ The second part of the advice takes up Cato's luna silenti post meridiem sine uento austro, "during the silent moon, in the afternoon, without south wind" (Cato, Agr. 40,1). And while Pliny's lunā sitiente clearly rephrases Cato's lunā silenti, Detlefsen suggested bracketing the parenthesis hoc est sicca as an explanatory gloss that had in all likelihood been interpolated from the earlier passage from the same book of Natural History $(17,57)$ where lunà siccā and lunà sitiente had appeared in close proximity. ${ }^{26}$

Despite doubts occasionally expressed over the correctness of the transmitted text in these passages, there can be little doubt that the expressions luna sitiente and lunā sicca existed and were used as doublets for lunā silenti. Unfortunately, their rareness does not allow us to determine whether Pliny's avoidance of luna silenti reflected a change in Latin usage (i.e. that contemporary Latin speakers viewed it as an archaism), or the expression was still current in Pliny's day, so that his preference for lunā sitiente (sicca) was idiosyncratic $^{27}$. Some stylistic difference between the two expressions cannot, of course, be ruled out (e.g. that one appeared slightly more archaic than the other), just as it is impossible to

23 Pintianus in Hermolaus Barbarus et al. 1668, 333 (on Plin. HN. 17, 57): "scribendum silente non sitiente ex Catone ipso, cap. 29"; cf. ibid. p. 351 (on Plin. HN. 17, 112).

${ }^{24}$ Cf. Detlefsen 1992 (1868), 66 ; Ian-Mayhoff 1892, 81; André 1964, 39; Rackham 1950, 40; König 1994,44

${ }_{25}$ Cato, Agr. 41, 2 and 40, 1; cf. André 1964, 147 n. 1 (on $\$ 112$ ).

${ }^{26}$ Detlefsen 1992 (1868), 76: "uncis inclusi"; Detlefsen's doubts regarding the authenticity of the parenthesis are shared by Rackham 1950, 78 and König 1994, 78 who actually omit hoc est sicca from the main text, as well as by Ian-Mayhoff 1892, 97 and André 1964, 58 who follow Detlefsen in bracketing the phrase. On the other hand, Lunais 1979, 329 accepts the parenthesis as genuine, even using it as proof that for Pliny the expressions luna sicca and sitiens were equivalent: "Il est évident que luna sicca, la lune sèche, est l'équivalent de luna sitiente et s'explique de la même manière. Pline écrit d'ailleurs un peu plus loin (XVII, 112) luna sitiente (hoc est sicca)".

27 Lunais 1979, 330 notes that the use of luna sitiente is restricted to two books of the Naturalis Historia: "Constatons simplement cette étrangeté, sans lui chercher d'autres raisons peut-être qu'un certain engouement très passager pour cette expression (scil. luna sitiente - M.K.) de la part de Pline au moment où il rédigeait les livres XVII et XVIII de son ouvrage". 
rule out that inhabitants of different regions of Italy did not yield a slight preference for one or the other term. It is, however, possible to explain the choice of the epithets sicca and sitiens and to establish a relative chronology for the expressions.

If one takes as the starting point the idea that the new moon (phase of the lunar cycle when the moon was not visible) was difficult to describe per se and that the easiest way to denote it was through an antonym of a visible, easily identifiable phase of the lunar cycle, it is easy to guess that the expression luna sicca was derived in contrast with the full moon, luna plena. The expression luna plena suggests that the moon orb was imagined as a vessel that is progressively filled up by some white liquid: the epithet siccus in this context is the closest antonym, suggesting not only emptiness (adjectives such as inaninis or vacuus would express that notion as well) but also the gradual drying up of the white light that had once filled the orb, as well as the certainty that eventually it will be filled up once more. ${ }^{28}$ There is in fact one context which illustrates very clearly this idea. In Lucius' prayer to the moon, the goddess' rays are qualified as "wet":

$<\ldots>$ ista luce feminea conlustrans cuncta moenia et udis ignibus nutriens laeta semina et solis ambagibus dispensans incerta lumina, quoquo nomine, quoquo ritu, quaqua facie te fas est invocare (Apul. Met. 11, 2, 3).

"You, who light up with your womanly light every city, and nourish with your wet fires joyous seeds, and dispense your fluctuating beams according to the motion of the Sun, by whatever name, by whatever rite, in whatever guise it is permitted to invoke you..."

M.Zimmermann, when discussing this passage, focuses on physical theories underlying the idea of the connection between the moon and moistness, and hence to vegetal growth $^{29}$. However, it seems even more probable that Apuleius was combining in this passage natural theories with popular lore, which called the phase when the moon was invisible the "dry" (sicca) moon, while the rays of the full moon could, by contrast, be characterized as "wet" - especially as Apuleius had stated specifically that on that night the moon was full and extraordinarily bright $($ Met. 11, 1, 1).

It is very probable that the terms luna siccia (describing the phase of the new moon as the exact opposite of the full moon) and luna silenti (describing it by contrast with the phase of the growing moon) coexisted for a fairly long time and were used interchangeably by the Latin speakers. While there is no proof that one is more archaic than the other, chances are that lunā siccā was created at a slightly later stage, as it seems to reflect a systemic view of the lunar cycle and a search for symmetry in the terminology for opposing phases of the moon, with plena luna opposed to sicca luna, just as luna crescens is

${ }^{28}$ For siccus of vessels, OLD 1968, 1755 (s.v. siccus 6b) cites two examples: Horace's stetit urna paulum / sicca "for a little while the jar stood empty" (Hor. Carm. 3, 11, 22-23) and, from the corpus Tibullianum, quem vestrum pocula sicca iuvant? "Which of you likes empty cups?" ([Tib.] 3, 6, 18). Naturally, the cognate siccare could be used of draining a vessel: siccat inaequalis calices conviva solutus / legibus insanis "every guest drains his cup, be it small or big (literally, cups of uneven size), not bound by insane laws" (Hor. Serm. 2, 6, 68-69); siccatoque avide poculo negat sibi umquam acidius fuisse "and having avidly drained the cup he declares that never had he tasted anything sourer" (Petron. Sat. 92); cf. bina die siccant ovis ubera "they drain twice a day the udder of the sheep" (Verg. Buc. 2, 42), etc.

${ }^{29}$ See Zimmermann 2012, 6-7, in particular: "Apuleius may have enjoyed wrapping his allusions to the above theories about the moistening effluences of the moon into one striking oxymoronic phrase" (ibid. 7). 
opposed to luna decrescens (it is worth noticing that earlier agricultural writers show a marked preference for the expression lunā silenti). As for the doublet lunā sitiente, there can be little doubt that it was a secondary, analogical creation under the influence of lun $\bar{a}$ silenti, combining the imagery of lunā siccā with the syntactical construction of the latter expression. Finally, the idea behind the epithets sicca and sitiens and the representation of the new moon as the "dry" or "thirsting" found additional support in the Roman lore, in particular, in the belief that the growth was linked to the quantity of dew that falls during the night. ${ }^{30}$

\section{Allusions to luna silens and luna sicca in Roman poetry}

We hope to have shown that the two designations of the new moon, luna silens and luna sicca (sitiens), were invented in opposition to different phases of the lunar cycle - the waxing moon and the full moon: in both cases, the search for the opposite expression was the guiding principle for creating the expression, so that the epithets silens and sicca are nothing more than antonyms of crescens and plena (respectively), and the appearance of the two expressions in agricultural texts show that for Latin speakers they were technical terms and did not carry particular poetic associations. However, Roman poets did not fail to notice the poetic potential of luna silens and luna sicca (sitiens), and Augustan poetry offers two passages where this potential is put to use - Verg. Aen. 2, 255 and Prop. 2, 17, 15. The remarkable fact is that in both passages, which have attracted a fair amount of attention from modern scholars, a reference to the agricultural term, suggested at some point, is rejected by the majority of commentators; as Vergil and Propertius allude to two different expressions and the contexts are not interconnected, the two passages are never considered in parallel: however, given the similarity in the approach of the two poets, a comparison seems to be worth the effort.

In Aen. 2, 250ff. Aeneas recounts the details of the Achaeans' ruse, stressing that the enemy had awaited nightfall before taking action, both inside and outside Troy:

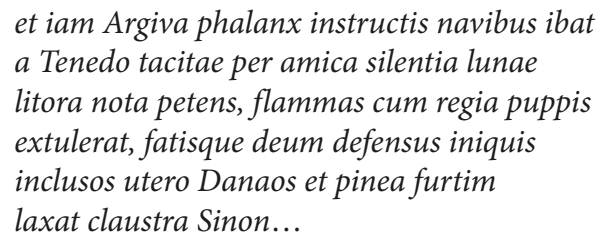

et iam Argiva phalanx instructis navibus ibat

a Tenedo tacitae per amica silentia lunae

litora nota petens, flammas cum regia puppis

extulerat, fatisque deum defensus iniquis

laxat claustra Sinon...

(Aen. 2, 254-259).

"And already the Argive phalanx was advancing on ships arranged in battle order from Tenedos thorough the benevolent silence of the quiet moon, seeking the well-known shores, when the

30 See Roscher 1890, 49-55; Tavenner 1918, 68. According to a very specific superstition, Thessalian witches had the power to bring down with their incantations a particular kind of poison (virus lunare, also described as venenum or spuma lunaris) from the moon and gather it as foam from the dewy grass (Lucan. 6, 506 and 669; Stat. Theb. 2, 284-285; Val. Flacc. 6, 447); I thank D. V. Keyer for calling my attention to this belief. The connection between the moon and the dew is so well established that it has misled some modern scholars into reconstructing the folk belief as the main cause for the expression luna sicca: cf. Shackleton Bailey 1947, 90 in his examination of the use of sicca... luna in Prop. 2, 17, 15, remarks after mentioning several passages where the waning moon is linked to tasks that demand dry conditions, "it is natural to suppose that $[. .$.$] sicca luna implies a dry atmosphere".$ 
flagship (literally, the royal deck) raised the flames into the air, and Sinon, protected by unjust fates of the gods, releases Danaans, locked in the [Trojan horse's] womb, and removes surreptitiously the pine bolts."

Verse 255 has been discussed by scholars and commentators since antiquity. The darkness and, to a lesser degree, the silence of the night that protected the Greeks had been stressed by Aeneas in previous verses (250-253); it would not then be out of place to emphasize once more the silence in which the fleet advanced: however, the wording of v. 255 with its almost tautological tacitae silentia lunae is peculiar. Already for ancient commentators the exact meaning of the line was not evident, and different interpretations were offered. Thus, Donatus, arguing with unnamed predecessors who considered the line a vitium scribentis, understood it as an indication that the first part of the night was moonless, whereas the moon came out later, and that it was then that the Greeks acted. ${ }^{31}$ Servius proposed two interpretations: tacitae silentia lunae was either used for artistic effect (this is also the interpretation preferred by Servius Danielis), or as an allusion to the Platonic conception of the music of the spheres. ${ }^{32}$ The first scholar to insist that tacitae silentia lunae could not fail to provoke the association with the expression luna silens was Angelo Politiano who followed Donatus in understanding the periphrasis as an indication that the moon was invisible for a part of the night; ${ }^{33}$ this suggestion was promptly dismissed by several scholars, including Scaliger, on the basis of the early epic tradition that Troy fell during the full moon. ${ }^{34}$ Since then scholars have been divided in their approach, with some accepting Politiano's idea, but the majority following Scaliger in rejecting the resemblance of tacitae silentia lunae to the agricultural term as accidental and irrelevant

31 Cf. Donat. Ad Aen. 2, 255: Multi vitium putant scribentis, ut qui dixit 'et ruit Oceano nox involvens umbra magna terramque pollumque Myrmidonumque dolos' hic diceret 'tacitae per silentia lunae.' Nullum in hoc vitium est si quidem nonnullae noctes habent primas partes tenebrosas, sequentes vero luna superveniente inlustris. Tale ergo noctis tempus elegerant Graeci quod tenebras haberet oportunas complendis insidiis et somni quietem daret et dehinc aliquid luminis e radiis lunae, et sine periculo vel errore venirent a Tenedo ad civitatis excidium. ("Many consider it to be an authorial error, that the same poet who said 'and the night falls, enveloping in her great shadow the earth and the heavens, and the Myrmidon ruses' (2, 251-255) now says 'through the silence of the quiet moon'. There is no error in this, as some nights are dark in the first part and illuminated in the later parts, when the moon comes out. This was the moment of the night that the Greeks chose, because it has darkness that is useful for accomplishing treachery and gives stillness of sleep, and later on some light from the moonbeams, so that they could arrive without risk nor error from Tenedos for the destruction of the people").

32 Thus, Servius, when discussing the expression, notes, Ad Aen. 2, 255: tacitae lunae: aut more poetico noctem significat aut physicam rationem dixit, nam circuli septem sunt, Saturni, Iovis, Martis, Solis, Veneris, Mercurii, Lunae. et primus, hoc est Saturni, vehementer sonat, reliqui secundum ordinem minus, sicut audimus in cithara. ("Quiet moon: either he thus poetically denotes the night, or explains the physical reasons. For there are seven circles, that of Saturnus, of Jupiter, of Mars, of the Sun, of Venus, of Mercury, of the Moon. And the first <of these>, i.e. Saturnus' circle, has deep sound, while the others less so, according to their order, just as we perceive in the case of the cithara.")

33 Politiano (1489, cap. 100) cites the use of luna silens in agricultural writers, and goes on to reconstruct from Vergil's description that the moon was alternatively visible and invisible on the night that Troy fell: "Nondum igitur luna lucebat, cum illi a Tenedo sub vesperam navigabant. Sed lucere tum coepit, cum iam urbem occupaverant. Non igitur aut sera fuerit, aut pernox luna, tum nec lunae quidem omnino coitus, sed tempus arbitror potius quandiu illa non luceret".

${ }^{34}$ For the overview of first responses to Politiano's interpretation, see the clear and succinct summary in Grafton, Swerdlow 1986, 212-213. 
to the understanding of Vergil's passage ${ }^{35}$ : this alternative interpretation sees in tacitae silentia lunae a simple indication that the night was a still, silent one, and presupposes that luna is largely equivalent to nox (as a sort of metonymy). ${ }^{36}$

Politiano's interpretation does in fact have one major weakness (and one that surprisingly does not seem to have been explicitly pointed out by his critics), namely, that the term luna silens is never used indifferently for any night without moonlight - it designates a specific phase of the lunar phase when the moon cannot be seen, regardless of whether the night sky is clear or not. This usage would seem to severely debilitate Politiano's idea that the periphrasis tacitae silentia lunae alluded to the fact that on the night that Troy fell the moon was not pernox. ${ }^{37}$ However, the expression tacitae silentia lunae is too pointed (to the point of becoming tautological) to be accidental; indeed, Statius, when reusing Vergil's phrase in his Thebaid, eliminated the pleonasm (per Arcturum mediaeque silentia lunae, Stat. Theb. 2, 58). In Vergil, deliberate juxtaposition of silentium and tacitus renders the association with luna silens unescapable; and the idea that luna could be used as a metonymy for nox does not gain unequivocal support from texts. ${ }^{38}$

A look at ancient sources on the fall of Troy suggests a certain solution as to the effect sought by Vergil in v. 255. Ancient scholars seem to have debated whether or not Troy was captured on a moonlit night. This problem seems to have arisen with a line from the

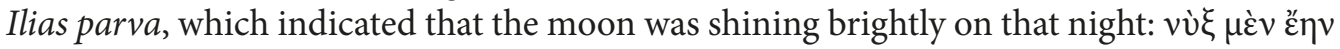

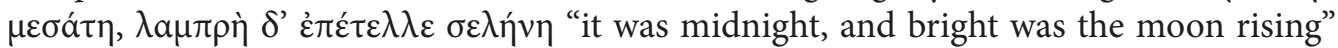
(fr. 9 Bernabé $)^{39}$. This line attracted attention of ancient scholars, who used it to deduce, with the help of astronomical observations, on which day of the year Troy was taken - an outline of the two positions of the issue by Callisthenes (ca. 360-327 BCE) is preserved in a scholium to Euripides' Hecube:

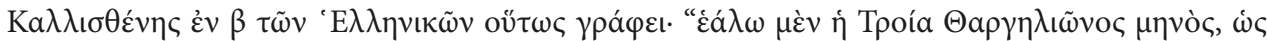

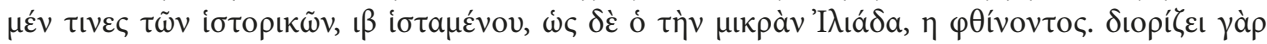

35 E.g., Austin 1964, 119-120 (on Aen. 2, 255) and Horsfall (2008, 226) with references follow Scaliger in rejecting Politiano's idea of Vergil evoking the term for the new moon; on the other hand, Marouzeau 1933, Cram 1936, Grafton, Swerdlow 1986, Barigazzi 1990 accept Politiano's general idea, corroborating or refining it each in his own way.

36 The idea that lunae stands for noctis goes back to ancient commentators of Vergil, appearing in Servius as one of the two possible explanations of tacitae lunae (aut more poetico noctem significat, aut..., Serv. Comm. in Aen. 2, 255 Thilo, Hagen). In modern scholarship this can be stated with varying degrees of explicitness: see Conington 1863, 133 (ad Aen. 2, 255), Heinze 1903, 24 n. 1, Cram 1936, 254 and 258 (with references); Barigazzi 1990, 228 is rightly and explicitly skeptical of the idea. Indeed, in a recent article Giardina 2006 went so far as to propose correcting lunae into noctis in v. 255; this correction is unnecessary and is not followed by editors (cf. Horsfall 2008, 227; Conte 2009, 42 makes no mention of it in his apparatus, ad loc.).

37 " $[. .$.$] potius accipimus tacitae lunae silentia lunam ipsam quam vocant silentem, hoc est minime$ tum quidem lucentem, ut latere insidiae magis possent, pulchra nimirum et eleganti tralatione ad auribus ad oculos" (Politiano 1489, cap. 100). The point that luna silenti is only used for a precise phase of the lunar cycle appears in argumentation, whether they be in favour or against Politiano's interpretation of this passage, only rarely (Marouzeau 1933 did note the term's application to the lunar cycle, but suggested that Virgil evoked it with a degree of poetic license, to speak of the moon temporarily disappearing behind clouds).

38 There are no traces of such usage in OLD 1968, 1050, s.v. lūna. In an independent search for examples of luna for nox in Latin poetry, we were able to find no good examples with the exception of Statius' mediaeque silentia lunae (Stat. Theb. 2, 58) which is clearly modelled on Vergil (Aen. 2, 255).

39 This fragment is preserved in three sources with minor adjustments of language: Clem. Alex. Strom. 1, 21, 104, 1; schol. in Eur. Hec. 910; schol. in Lycophr. Alex. 344. We quote the text as reconstructed by Bernabé in his edition. 


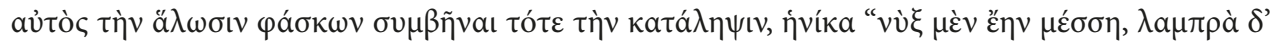

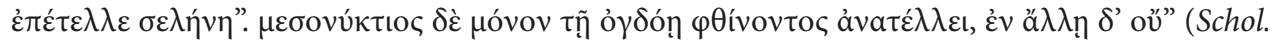
in Eur. Hec. 910).

"Callisthenes in the second book of his Hellenica writes thus: 'Troy was taken during the month of Thargelion, according to some historians, on the twelfth day when the moon was waxing, but according to the author of the Little Iliad on the eighth day when the moon was waning. For he determines the capture when he later says that the city was taken when 'it was midnight, and bright was the moon rising' (fr. 9 Bernabé). For it rises at midnight only on the eighth day of the waning moon, and on no other day."

This testimony is remarkable in that it shows that the date of the fall of Troy was discussed in pre-Alexandrian times: the scholium goes on to state that Callisthenes' position was opposed by Lysimachus. However, there can be little doubt that the discussion was taken over by Hellenistic scholarship, and Vergil, with his thorough knowledge not only of the Greek epic tradition but also of Alexandrian studies and discussions of Homer, would most certainly have been aware of the issue: moreover, in this case we can be certain that he would have specifically looked into the matter, when working on Aeneas' account of the fall of Troy, as the presence or absence of moonlight is important for the perception, and even for the development, of events of that night ${ }^{40}$. Modern commentaries to Vergil cite a series of passages from the second book of the Aeneis pertaining to the question of moonlight: thus, Vergil stresses the darkness of the night in v. 250-251 (ruit Oceano nox / involvens umbra magna terramque polumque), v. 360 (nox atra), v. 397 (nox caeca), v. 420 (obscura nocte), but pointedly mentions moonlight in v. 340 (oblati per lunam). It is evident from this list that in some cases Vergil preferred to stress either the glimmer of light or the darkness of the night (which, incidentally, would have been congruent with the subjectivity of Aeneas' account). However, in v. 255 the choice of words seems to suggest that Vergil was alluding to the scholarly debate on the presence or absence of moonlight ${ }^{41}$. Vergil clearly imagined the night as moonlit, and the association with the term luna silenti was introduced in order to show that he was aware of the issue and to subtly emphasize his own position. In the absence of the context of fr. 9 Bernabé, it is difficult to establish whether Vergil's wording in Aen. 2, 255 would have made his readers think specifically of the Ilias parva. ${ }^{42}$ However, for a reader unaware of the discussion regarding the day of the month on which Troy was captured, the expression tacitae per amica silentia lunae would appear as a kind of poetic exaggeration that likened the moon to a silent witness standing by the Achaeans' ruse. ${ }^{43}$

Another passage from Augustan poetry seems to offer an instance of similar play with the astronomical term. In 2, 17 Propertius uses the expression sicca... luna in the description of his unhappiness since he has fallen out of favour with Cynthia:

40 The fact that Vergil deliberately shifts his emphasis from moonlight to darkness throughout the account of the events of that night, was rightly stressed by Heinze 1903, 24-25; cf. Barigazzi 1990, 237: „Ĺscurità della notte è un fatto obiettivo e non si può pretendere che il poeta, intento a trarre dal buio effetti particolari, precisi o sfumi ogni volta le gradayioni fra le tenebre e le luci".

41 Thus, also Cram 1936, 258-259; Grafton, Swerdlow 1986, 218; cf. Barigazzi 1990, 235.

42 Cf. Severyns 1926, 301 who characterizes the parallel as "une ressemblance trop vague pour qu'on en puisse tirer argument".

${ }^{43}$ Cf. Horsfall 2008, 226 (ad Aen. 2, 255): "in [Vergil] the moon's silence belongs to a general tendency to 'humanise' nature [...] and here that silence may also suggest her connivance, as a kind of celestial accomplice, at Greek trickery". 
durius in terris nihil est quod vivat amante,

nec, modo si sapias, quod minus esse velis.

quem modo felicem Invidia maerente ferebant,

nunc decimo admittor vix ego quoque die,

nec licet in triviis sicca requiescere luna

aut per rimosas mittere verba fores

(Prop. 2, 17, 9-12; 15-16)

"There is no human nor beast that lives a harder life than the lover, and none that you would wish less to be. I, who only a while ago was considered blessed, as Envy gnashed her teeth, now scarcely gain access < to my beloved $>$ once in ten days; nor am I permitted to lie on streets, when the moon is dry, or to direct my words through the cracks in her door". 44

The poet is only rarely admitted to Cynthia's presence, he cannot even try to persuade his beloved through the closed doors. ${ }^{45}$ The meaning of in triviis requiescere has been interpreted as referring either to former love encounters with Cynthia on crossroads, or, more convincingly, to Propertius' vigils by the doorstep of his beloved. ${ }^{46}$ Turning to sicca luna, most modern commentators, as was the case with Aen. 2, 255, insist on dissociating Propertius' choice of epithet from the term used by agricultural writers, arguing that the poet was simply referring to a clear, dry night. ${ }^{47}$ On the rarer occasions, when the association of Propertius' siccā lunā with the term for the new moon is recognized, the poet's meaning is reconstructed through popular beliefs. Thus, Shackleton Bailey tried to explain the expression siccā... lunā in Prop 2, 17, 15 through the belief that the dew that falls during the night, and especially its quantity, depends on the moon and its phase:

44 The transposition of v. 15-16 was first proposed by Lachmann 1973 (1816), 164. For a long time, the majority of editors were convinced by Lachmann's arguments and accepted the transposition; however, Cairns 1975 has argued that the order of lines as they appear in manuscripts may be retained.

${ }^{45}$ Manuscripts give the verb in v. 15 as licet, but whether this is the right modality for Propertius' context, has been called into question by some editors: thus, Guyet (Guyetus) suggested correcting the verb into libet, and Herzberg into iuvat. Heyworth in his recent edition (Heyworth 2007a, 63) follows Guyet, explaining his reasons in his companion to the text of Propertius: "There seems to be no point in the introduction 'and it is not possible': what is stopping him? It cannot be the dangers of the crossroads at the new moon, as sicca luna is so placed that it qualifies only in triviis requiescere. Better would be nec libet (or iuvat): he no longer cares to play the part of the deserted lover $\langle\ldots\rangle$ This is what I print; but to be franc I am puzzled" (Heyworth 2007b, 186-187). I believe that the manuscript reading should be retained, and that it suits with Propertius' wordplay in this passage, as explained below.

${ }^{46}$ The former interpretation has been prompted above all by the resemblance of Prop. 2, 17, 15 to 4, 7, 19-20 which does in fact speak explicitly to love-making in trivio (thus, Enk 1962, II, 249; Butler, Barber 1933, 220 on Prop. 2, 17, 15-16.13-14; Shackleton Bailey 1947, 91). Lately, however, the explanation has shifted to understanding both verses of the distich 15-16 as play with the motif of exclusus amator (Cairns 1975; Thomas 1980; Fedeli 2005, 519-520 on Prop. 2, 17, 11-12.15-16). This interpretation does seem preferable, as it explains the choice of the verb requiescere, and brings out the continuity between verse 15 and 16 (for fuller argumentation, see Fedeli 2005, 520).

47 Butler, Barber 1933, 220 (ad Prop. 2, 17a, 15-16, 13-14): “The sense is uncertain. [...] Probably it means no more than that the air is dry, the moon is clear and bright"; this interpretation appears also in Camps 1967, 138 (ad loc.), Enk 1962, II, 249, ad loc. ("ego credo lunam siccam vel sitientem esse "lunam fulgentem in sicco aethere”), as well as by Rotstein 1920, 326 (ad loc.), who adds: „Es ist keine Feuchtigkeit in der Luft, so daß der Mond hell leuchtet". Cf. Lunais 1979, 330: "Une telle précision (scil. la nuit passée à la nouvelle lune - M.K.) apparaît à la fois bien prosaïque et bien inutile, pour ne pas dire encombrante, dans un poème tout empreint de lyrisme mélancholique". 
"Since dew falls from the moon the deduction is obvious that when there is no dew it is because the moon is temporarily short of moisture, sicca; and sicca luna will be another way of saying rore non cadente. It is therefore an error to suppose that cold and clear conditions are implied; rather the reverse, for it is on cloudless nights that the dew comes thickest, an observation which no doubt led to the popular theory of its lunar origin" (Shackleton Bailey 1947, 90-91).

Similarly, Heyworth suggested that sleeping on the street on the night of the new moon would be particularly dangerous for an exclusus amator, as on that night Hecate and other infernal forces would be roaming the streets. ${ }^{48}$ Finally, O’Neil, in line with his idea that Cynthia is associated with the moon throughout Propertius' ceuvre, suggested that in Prop. 2, 17, 15 the epithet sicca was used as a synonym for frigida, with an erotic double-entendre: ${ }^{49}$ however, his explanation of Propertius' meaning is very vague, and while he stresses that in triviis requiescere must refer to the poet's love encounters with Cynthia on crossroads, he does not explain exactly how the calembour reconstructed for sicca luna would relate to the situation.

None of the previously mentioned explanations is satisfactory either. The interpretation that sees in the expression sicca luna a reference to a clear, dry night would imply that Propertius was ready to pass his vigils by Cynthia's door only in comfortable meteorological conditions; Shackleton Bailey's suggestion that the phrase referred to a cloudy night without dew is open to similar criticism, while it seems to rely to an even greater degree on a conjectural reconstruction of the situation without substantial support from the text; ${ }^{50}$ neither is there anything to support Heyworth's suggestion that Propertius was referring to popular superstitions about Hecate and her followers roaming the crossroads on the night of the new moon.

However, there seems to be one interpretation that could explain Propertius' meaning, while avoiding the weaker points of earlier explanations. Unless one is willing to discard the expression luna $\overline{s i c c} \bar{a}$ as attested only in Pliny the Elder, it is unlikely that Propertius' readers would have failed to associate the expression sicca luna in Prop. 2, 17,15 with the agricultural term, and it is, in fact, precisely this association that seems to offer the key to understanding the passage: if the entire distich Prop. 2, 17, 15-16 is taken as an enumeration of the (slightly exaggerated) woes of the exclusus amator, who, besides being banished from Cynthia's presence, is also forbidden to enjoy the usual activities of exclusi amantes (i.e. sleeping by his beloved's house or trying to convince her to let him in), the sicca luna of v. 15 would be a tongue-in-cheek allusion not only to (moonless) nights that he would wish but is forbidden to spend in the street by Cynthia's house, but also to Cynthia's refusal to show herself to her lover. ${ }^{51}$ Propertius' wording thus evokes the strict terminological usage of luna siccā, exploiting in the meanwhile the poetic potential that the expression, if taken literally, carried.

${ }^{48}$ Heyworth 2007b, 187 n. 51: "At the new moon Hecate and her followers would be at large, making the crossroads especially dangerous".

49 O'Neil 1958, 5; the idea however is evoked with approval by Fedeli 2005, 520 (ad Prop. 2, 17, 11-12, 15-16).

${ }^{50} \mathrm{Cf}$. in particular, his evocation of the dangers of malaria of which there is no hint in Propertius' text (Shackleton Bailey 1947, 91).

${ }^{51}$ For the designation of the moon by the epiclesis Cynthia, cf. Lucan. 1, 218; 4, 60; 8, 721; Petron. Sat. 122, line 130; Sil. Ital. Pun. 4, 480; Stat. Theb. 1, 577; Val. Flacc. 2, 56; etc. 


\section{Conclusion}

We hope to have shown that the expressions of the new moon in Latin, lunā siccā and lunā silenti, were originally created by opposition to other visible and thus easily identifiable phases of the lunar cycle, i.e. to the waxing moon and to the full moon, respectively. There was thus no poetic impulse behind the creation of these expressions, which accounts for their unremarkable usage in agricultural writers. However, there are traces of a certain recognition in Roman literature of the poetic potential of these expressions, if taken literally. Thus, in Prop. 2, 17, 15 the expression sicca luna is used not only to evoke the astronomical term, but also as part of wordplay, likening his current banishment from Cynthia's presence to the changeability of the moon. In Verg. Aen. 2, 255 the expression tacitae per amica silentia lunae hinted at the scholarly debate regarding the day of the lunar cycle, endowing the moon at the same time with personal traits, so that it appears as a silent, benevolent witness to the Achaeans' ruse. Vergil's wording is close enough to the term luna silenti to create the association with the particular phase of the lunar cycle; however, it is adapted to the context, as the poet brings out the metaphor present in lun $\bar{a}$ silenti, if the participle silens is taken in its literal sense, combining both visual and auditive associations in one expression. ${ }^{52}$

\section{References}

André J. (ed., comm.) Pline l'Ancien: Histoire naturelle, livre XVII. Paris, Belles-lettres, 1964.

Austin R. G. (ed., comm.) P. Vergili Maronis Aeneidos liber secundus. Oxford, Clarendon Press, 1964.

Ash H.B. (ed., transl.) Lucius Junius Moderatus Columella, vol. I: On agriculture I-IV. Cambridge, Mass., Harvard University Press, London, Heinemann, 1941.

Barigazzi A. Verg. Aen. 2.55 tacitae per amica silentia lunae. Prometheus 1990, 16 (3), 227-237.

Brightman F. E. Some Dante Notes. Modern Language Revue 1919, 14 (3), 326-330.

Butler H.E. Barber E. A. (ed., comm.) The Elegies of Propertius, edited with an Introduction and Commentary. Hildesheim, Zürich, New York, Olms, 1996 (Oxford 1933).

Cairns F. Further Adventures of a Locked-Out Lover: Propertius 2.17, University of Liverpool Inaugural Lecture. Liverpool, Liverpool University Press, 1975.

Camps W. A. (ed., comm.) Propertius, Elegies Book II. Cambridge, CUP, 1967.

Conington J. (ed., comm.) P. Vergili Maronis opera: the Works of Virgil with a Commentary, vol. II. London, Whittaker - George Bell, 1863.

Cram R. V. On a Verse in Vergil Aeneid II. 255 and the Post-Homeric Tradition Concerning the Capture of Troy. CPh 1936, 31 (3), 253-259.

Detlefsen D. (ed.) C. Plinii Secundi Naturalis Historia, vol. I-III. Hildesheim - Zürich — New York, Olms, 1992 (Berlin, 1868-1871).

Enk P. J. (ed., comm.) Sex. Propertii elegiarum liber secundus, vol. I-II. Leiden, Sijthoff, 1962.

Ernout A. (éd., tr., comm.) Pline l'ancien, Histoire Naturelle, livre XXVIII. Paris, Belles-lettres, 1962.

Ernout A. Meillet A. Dictionnaire étymologique de la langue latine: histoire des mots. Paris, Klincksieck, 1967.

Fedeli P. (ed., comm.) Properzio, Elegie libro II: Introduzione, testo e commento. Cambridge, Francis Cairns, 2005.

Georges K.E. Ausführliches Lateinisch-Deutsches Handwörterbuch aus den Quellen zusammengetragen, Bd. I-II, Leipzig, Hahn'sche Verlagsbuchhandlung, 1880.

Giardina G. Verg. Aen. 2, 225: Una crux esegetica o una crux testuale? QUCC 2006, 83 (2), 93-95.

52 Cf. Barigazzi 1990, 232: "Ma la corrispondenza con la frase catoniana (scil. lunā silenti - M. K.) sarebbe da vedere piuttosto in tacitae lunae per la non rara trasposizione dal piano visivo a quello uditivo, come nei noti passi danteschi mi rispindeva là dove il sol tace (Inf. 1.60), io venni in loco d’ogni luce muto (Inf. 5.28)". Indeed, it has been argued that these two passages in Dante had been inspired by Vergil (Brightman 1919, 327-329). 
Grafton A. T. Swerdlow N. M. Greek Chronography in Roman Epic: The Calendrical Date of the Fall of Troy in the Aeneid. CQ 1986, 36 (1), 212-218.

Green C. M. C. Roman Religion and the Cult of Diana at Aricia. Cambridge - New York, CUP, 2007.

Heinze R. Virgils epische Technik. Darmstadt, Wiss. Buchgesellschaft, 1965.

Heyworth S. J. (ed., comm.) Sexti Properti Elegi critico apparatu instructi. Oxford, Clarendon Press, 2007.

Heyworth S. J. Cynthia: A Companion to the Text of Propertius. Oxford, OUP, 2007.

Horsfall N. (ed., tr., comm.) Virgil, Aeneid 2: A Commentary. Leiden - Boston, Brill, 2008.

Ian L. Mayhoff C. (eds). C. Plini Secundi Naturalis Historiae libri XXXVII, vol. III: libri XVI-XXII. Leipzig, Teubner, 1892.

König R. (ed., tr.) C. Plinius Secundus d. Ä.: Naturkunde, Buch XVII. Darmstadt, 1994.

Kuijper D. Minorem ad lunam. Mnemosyne 1966, 19 (1), 38-41.

Lachmann C. (ed., comm.) Sextus Aurelius Propertius: Carmina. Hildesheim, New York, Olms, 1973 (= Leipzig 1816).

Lunais S. Recherches sur la lune: I. Les auteurs latins de la fin des Guerres Puniques à la fin du règne des Antonins. Leiden, Brill, 1979.

Marouzeau J. Quelques interprétations de Virgile. RÉL 1933, 11 (1), 64-66.

Mikalson, J. D. The Noumenia and Epimenia in Athens. HTR 1972, 65(2), 291-296.

Nisbet R. G. M. Rudd N. (comm.) A Commentary on Horace: Odes, Book III. Oxford, OUP, 2004.

O’Neil E. N. Cynthia and the Moon. CPh 1958, 53 (1), 1-8.

Politiano A. Miscellaneorum centuria prima. Florence, Miscomini, 1489.

Rackham H. (ed., tr.) Pliny, Natural History, vol. V: Books XVII-XIX. Cambridge, Mass., Harvard University Press, London, Heinemann, 1950.

Riess E. Aberglaube, in: RE 1893, I/1, 29-93.

Roscher W.H. Über Selene und Verwandtes, mit einem Anhange von N. G. Politis. Leipzig, Teubner, 1890.

Rotstein M. (ed., comm.) Die Elegien des Sextus Propertius, Bd. I. Berlin, Weidmann, 1920.

Severyns A. Le cheval de Troie (Petite Iliade, fragm. XXII). Revue belge de philologie et d'histoire 1926, 5 (23), 297-322.

Shackleton Bailey D. R. Interpretations of Propertius. CQ 1947, 41 (3-4), 89-92.

Tavenner E. The Roman Farmer and the Moon. TAPhA 1918, 49, 67-82.

Thomas Ph. L. Dry Moon and Thirsting Lover: Propertius II. 17. Latomus 1980, 39 (1), 109-120.

Zimmermann M. Text and Interpretation, Interpretation and Text, in: W. Keulen, U. Egelhaaf-Gaiser (eds). Aspects of Apuleius' Golden Ass III: The Isis Book, A Collection of Original Papers. Leiden, Boston, Brill, 2012, 1-28.

Received: February 12, 2019

Accepted: April 14, 2019 